Trowell, H. C., Davies, J. N. P. \& Dean, R. F. A. (1952). Brit. med. F. ii, 798.

Van der Sar, A. (195 I). Docum. neerl. indones. Morb. trop. 3, 25.

Véghelyi, P. V. (1949). Pediatrics, 3, 749.

Viollier, G. (195I). Liver Disease. A Ciba Foundation Symposium. London: J. and A. Churchill.

Walt, F., Wills, L. \& Nightingale, R. P. (1950). S. Afr. med. F. 24, 920.

Waterlow, J. C. (1948). Spec. Rep. Ser. med. Res. Coun., Lond., no. 263.

Waterlow, J. (r950). Lancet, 258, go8.

Waterlow, J. C. (195 I). W. Indies med. F. 1, 15.

\title{
The Relationship between Calcium Retention and Body Stores of Calcium in the Rat: Effect of Age and of Vitamin D
}

\author{
By KATHLEEN M. HENRY AND S. K. KON \\ National Institute for Research in Dairying, University of Reading
}

(Received 6 Fune 1952)

It is known that the rate of calcium absorption decreases with progressive calcification of the skeleton (see e.g. Fairbanks \& Mitchell, 1936; Rottensten, I938; Mitchell, 1939; Macy, 1942; Nicolaysen, 1943; Henry \& Kon, 1947; Kane \& McCay, 1947); normally an adult stage is reached when the animal no longer deposits $\mathrm{Ca}$ in its bones and when excretion balances the intake. However, with advancing age the process goes further and increased katabolism leads to loss of bone salts (McCay, Crowell \& Maynard, 1935; Meulengracht, I938; Todd, 1942; Stare, I943; Henry \& Kon, 1947). Henry \& Kon (1947) found that rats, having retained when I month old $96 \%$ of the $\mathrm{Ca}$ from a diet containing $0.13 \%$ of it and $0.23 \%$ phosphorus, 2 years later not only retained no $\mathrm{Ca}$ when given the same diet but, on the contrary, lost it from their bodies. Between the metabolic tests, of which there were, all told, four during the 2 years, the animals received our stock-colony diet (Folley, Ikin, Kon $\&$ Watson, I938), which supplies ample quantities of $\mathrm{Ca}$, and there is no doubt that while on this diet they had full opportunity to replenish their stores. It is known that in young rats the efficiency of absorption of $\mathrm{Ca}$ at any one age depends on the degree of saturation of the body, the retention being better when the stores are relatively low (Fairbanks \& Mitchell, I936; Rottensten, 1938; Nicolaysen, 1943). Outhouse, Kinsman, Sheldon, Twomey, Smith \& Mitchell (1939) found similar relationships in children.

As just pointed out, the old rats of Henry \& Kon (1947) were in all probability well calcified before the metabolic tests with the low-Ca diet on which they went into negative $\mathrm{Ca}$ balance. It seemed of interest, therefore, to determine the behaviour in relation to age of rats with body stores saturated to different degrees.

\section{EXPERIMENTAL}

\section{General plan of the experiments}

In long-term experiments litter-mate rats were given diets containing different levels of $\mathrm{Ca}$ and $\mathrm{P}$. The diet lowest in $\mathrm{Ca}$ supplied it in amounts definitely suboptimal for young, rapidly growing animals. This diet was used for the metabolic study, at 
3 -monthly intervals during 2 years, of $\mathrm{Ca}$ retention by animals of all groups, adequate vitamin $D$ being given throughout the experiment.

When planning these experiments we had the opportunity to discuss them, as well as our earlier work, with Professor Nicolaysen of Oslo. He (Nicolaysen, 1943) had claimed that in growing rats there is an endogenous factor regulating $\mathrm{Ca}$ absorption, but that this factor is without effect in the absence of vitamin $\mathrm{D}$. He considered that animals given a diet rich in $\mathrm{Ca}(0.8-0.9 \% \mathrm{Ca})$ and $\mathrm{P}$ and no vitamin $\mathrm{D}$ might, at the end of $\mathrm{I}$ or 2 years, retain $\mathrm{Ca}$ more efficiently with a vitamin D supplement, than litter-mates given the same diet with vitamin $\mathrm{D}$ from weaning. An experiment on these lines was therefore carried out and subsequently further experiments were done to study the effect of vitamin $\mathrm{D}$ on $\mathrm{Ca}$ absorption in the adult rat.

\section{Diets}

\section{Exp. I. Effect of age and of body stores of calcium on calcium retention}

The diets were designed to contain about $0.13,0.4$ or $0.8 \% \mathrm{Ca}$. The low-Ca basal diet (diet 24I, $0.13 \% \mathrm{Ca}$ ) was essentially that described by Sherman $\&$ Booher (193I) and consisted of one part whole dried milk and nine parts whole wheat; $4 \%$ of the salt mixture of de Loureiro (193I), with the calcium phosphate omitted, replaced an equivalent amount of wheat. The $\mathrm{Ca}$ and $\mathrm{P}$ content of this diet was increased by the addition of suitable amounts of $\mathrm{CaHPO}_{4}, 2 \mathrm{H}_{2} \mathrm{O}$ to give diets 242 or 248 . The compositions and analyses of the diets are shown in Table I. A separate (weekly) supplement of cod-liver oil of known vitamin $\mathrm{D}$ potency was given to all rats to supply daily about 0.5 i.u. as vitamin $\mathrm{D}_{3}$. The animals received distilled water to drink.

\section{Animals and technique}

Forty-two sets of three litter-mate male rats were used. The rats were weaned from mothers on our stock diet (Folley et al. 1938) when 2 I days old, and animals in each litter were allocated by lot to diet 24I (group I), diet 242 (group 2), or diet 248 (group 3). The newly weaned animals were given their respective experimental diets for 6 days and were then placed in metabolic cages, where all received diet 24I. The excreta were discarded for $\mathrm{I}$ week and then collected for 3 weeks and analysed for $\mathrm{Ca}$ and $\mathrm{P}$. Two types of metabolic cage were used and their description, together with details of methods of collection and analysis of the excreta, will be found in an earlier publication (Henry \& Kon, 1937). At the end of the metabolic test the animals were taken out of the metabolic cages, put in twos or threes in stock-colony cages and given the diets they had before the test. Further metabolic tests, always with diet 24r, in which excreta were discarded for I week and subsequently collected for 2 weeks, were carried out when the animals were $3,6,9,12,15,18,21$ and 24 months old. After the initial test with groups of eight rats on each diet, groups of four rats only could be used, since it was necessary to keep them in the larger metabolic cages of Ackroyd \& Hopkins ( 1916 ) of which only twelve were available. Previous experience (Henry \& Kon, 1947) had shown that after I year deaths were likely to occur among the animals. As far as possible the metabolic tests were on four of the original eight 
litters at $3,9,15$ and 21 months and on the remaining four litters at $6,12,18$ and 24 months. In the 2 nd year of the experiment all rats in a group were given diet $24 \mathrm{I}$ when a metabolic test was being carried out; previously only those animals on actual test received it.

One month before the 18 -month test the retention of $\mathrm{Ca}$ from their own basal diets ( 242 or 248 ) was measured with groups 2 and 3 . They then continued on their own diets for another week before being used in the metabolic tests with diet 24I.

In one instance in the earlier experiments (Henry \& Kon, 1947) metabolic tests with old rats, previously kept as usual on the stock diet, were done for two consecutive fortnightly periods to detect any signs of adaptation to the low-Ca diet. The outcome then was negative, but, since the time allowed for adaptation was relatively short, similar tests were now done again, but rats in groups 2 and 3 received the low-Ca diet $24 \mathrm{I}$ for the 3 months between the metabolic tests at 21 and 24 months. In this way during the last 3 months of the experiment all rats received diet $24 \mathrm{I}$.

At the beginning of the last (24 months) test only three complete litters were available, in the fourth litter group 3 was not represented; moreover, one animal in group I died in the course of the test. At the end of this last collection period all surviving animals were killed, and the right hind-legs were $\mathrm{X}$-rayed; humeri and femora were then removed and the moisture, ash, $\mathrm{Ca}$ and $\mathrm{P}$ content of the right bones were determined.

The remaining thirty-four sets of litter-mates were treated in exactly the same way as the eight used in the metabolic experiments. After each period on diet $24 \mathrm{I}$ three sets were killed, the same analyses being carried out on the bones as at the end of the metabolic tests.

\section{Exps. 2, 3 and 4. Effect of vitamin $D$ on the retention of calcium by the adult rat}

\section{Diets}

The compositions and analyses of the diets used in these experiments are given in Table I.

\section{Animals and technique}

Exp. 2. Eight litters of six male rats were weaned from our stock diet (Folley $e t$ al. 1938) and given a diet containing about $0.8 \%$ of both Ca and P (diet 252, Table 1 ). All animals received carotene twice a week to supply ${ }_{5} 5$ i.u. daily. In each litter two rats had in addition $70 \mathrm{i} . \mathrm{u}$. vitamin $\mathrm{D}$ once a week. At the end of I year one rat given vitamin $\mathrm{D}$ and one without it from each of five litters were placed in metabolic cages and from now on the so far untreated animals received vitamin D. Excreta were discarded for I week and then collected for 2 weeks and analysed for $\mathrm{Ca}$ and $\mathrm{P}$. At the end of the collection period these animals, together with a third litter-mate that had received no vitamin $\mathrm{D}$ from weaning, were killed and the bones taken for analysis and X-ray examination as described in Exp. I. A sixth pair was started but had to be discarded on account of excessive loss of weight by one animal. The remaining two litters were kept for future use. Another metabolic test was done with the surviving animals a year later. It was intended that this test should be made 
with the litter-mates of those rats used in the I-year test, but this was not always possible, some animals having died during the interval. Hence animals from the spare litters were used, but even with those only five pairs were available.

Table I. Percentage composition of diets used and their content of $\mathrm{Ca}, P$ and moisture

Diet no.

\begin{tabular}{|c|c|c|c|c|c|c|c|}
\hline Component & $24 \mathrm{I}$ & 242 & 248 & 252 & 306 & 3 IOA & 3 IOB \\
\hline Wheat, whole ground & 86 & $85 \cdot 1$ & 83.9 & 54.5 & 85.7 & $82 \cdot 2$ & $83 \cdot 3$ \\
\hline Milk & Io & $9 \cdot 9$ & $9 \cdot 7$ & - & $9 \cdot 9$ & - & - \\
\hline dried skim & - & - & - & $19 \cdot 8$ & - & - & - \\
\hline Yeast, dried brewer's & - & - & - & $4 \cdot 0$ & - & $2 \cdot 9$ & $3 \cdot 0$ \\
\hline Linseed cake & - & - & - & II $\cdot 0$ & - & - & - \\
\hline Casein, crude & - & - & - & $4 \cdot 7$ & - & - & - \\
\hline Egg albumin & $\cdots$ & - & - & - & - & $2 \cdot 0$ & $2 \cdot 0$ \\
\hline Wheat gluten & - & - & - & - & - & $9 \cdot 7$ & $10 \cdot 0$ \\
\hline Groundnut oil, semi-hardened & - & - & - & $4 \cdot 0$ & - & - & - \\
\hline Ca- and P-free salts (see p. I48) & 4 & $4 \cdot 0$ & $3 \cdot 9$ & - & $4^{\circ} \mathrm{O}$ & - & - \\
\hline $\mathrm{NaCl}$ & - & - & - & 0.5 & - & r.o & $\mathrm{I} \cdot \mathrm{O}$ \\
\hline Ferric citrate & - & - & - & - & - & 0.2 & 0.2 \\
\hline $\mathrm{CaCO}_{3}$ & - & 一 & - & 0.5 & - & I.0 & 0.5 \\
\hline $\mathrm{CaHPO}_{4} \cdot 2 \mathrm{H}_{2} \mathrm{O}$ & - & I'o & $2 \cdot 5$ & - & 0.4 & $1 \cdot 0$ & - \\
\hline Steamed bone-flour & - & - & - & $1 \cdot 0$ & - & - & - \\
\hline $\mathrm{Ca}$ & 0.1265 & 0.3915 & 0.7663 & 0.7850 & 0.2472 & 0.7346 & 0.26 \\
\hline & $\begin{array}{l}0.3939 \\
13.41\end{array}$ & $\begin{array}{l}0.5937 \\
13.04\end{array}$ & 0.8754 & 0.7654 & $0.475 \mathrm{I}$ & 0.6555 & 0.30 \\
\hline Moisture & 13.41 & 13.04 & & $12 \cdot 18$ & 13.19 & 12.01 & \\
\hline
\end{tabular}

* Unfortified dried whole milk released as required by the Ministry of Food. Different batches were therefore used and in consequence the $\mathrm{Ca}$ and $\mathrm{P}$ content of different batches of diet varied to some extent. Mean figures for all batches are quoted here but the appropriate values were used for calculations in different experiments.

Exp. 3. Eight litters of eight male rats were weaned on to diet 252. All animals were given carotene as in Exp. 2 and three animals in each litter had vitamin $D$ at the rate of ro i.u. daily. When they were 9 months old, one animal receiving vitamin $D$ and one without it were taken from each of six litters, put into metabolic cages and given diet 306 ('Table I). This diet had the same Ca content as that used by Nicolaysen (1943). The experimental procedure was the same as in Exp. 2, all animals again being given vitamin D. A third control rat from each litter was given diet 306 during the metabolic test and was killed at the same time as its litter-mates. These control animals had no vitamin $\mathrm{D}$ at any time and served as controls for the final bone analyses.

It was originally intended to carry out further tests at a later date with the surviving litter-mates. The results of the earlier tests (see p. I 54), however, failed to show the differences in $\mathrm{Ca}$ absorption observed by Nicolaysen (r943) with 8-month-old rats. The experiment was, therefore, discontinued and a further one was done.

Exp. 4. Six litters of six male rats were weaned on to diet 3 IOA (Table I). This was Nicolaysen's (r943) high-Ca and P diet. All animals were given carotene and three in each litter 20 i.u. vitamin $D$ daily as cod-liver oil. When the rats were 8 months old, four (two given vitamin $\mathrm{D}$ and two not) from each litter were placed in metabolic cages; the remaining two rats in each litter were discarded. One of the animals 
receiving vitamin $\mathrm{D}$ continued on the high-Ca diet while the other one was given a low-Ca diet (diet 310B, Table I); the pairs receiving no vitamin D were treated in the same way. All rats were given 20 i.u. vitamin D daily for the remainder of the experiment. The treatment of the four groups of rats may be summarized as follows: group 1, high-Ca diet throughout, vitamin D throughout; group 2, high-Ca diet throughout, vitamin D from 8 months onwards only; group 3, high-Ca diet for 8 months then low-Ca diet, vitamin D throughout; group 4, high-Ca diet for 8 months then low-Ca diet, vitamin D from 8 months onward only. Excreta were discarded for 3 days and then collected for $\mathrm{I}$ week and analysed for $\mathrm{Ca}$ and $\mathrm{P}$. At the end of the collection period all animals were given the high-Ca diet (3IOA) supplemented with vitamin $\mathrm{D}$ for $\mathrm{I}$ month, when the rats in groups 3 and 4 were again given the low-Ca $\operatorname{diet}(3 \mathrm{IOB})$ and another collection of excreta was made from each of the four groups. The procedure adopted with group 4 was the same as that described by Nicolaysen (1943). No bone analyses were made at the end of the experiment, as all animals had received vitamin $D$ for at least 7 weeks and no differences in calcification could be expected.

\section{RESULTS}

Exp. I. Effect of age and of body stores of calcium on calcium retention

The mean results for $\mathrm{Ca}$ and $\mathrm{P}$ balances are given in Table 2, and those for the bone analyses in Table 3 .

\section{Metabolism of calcium}

It will be seen from Table 2 that the retention of $\mathrm{Ca}$ from the low-Ca diet (24I) was throughout the experiment more efficient in group $\mathrm{I}$ than in groups 2 and 3 .

The animals in group I behaved as might have been anticipated. Over $90 \% \mathrm{Ca}$ was retained from diet 24I (suboptimal in $\mathrm{Ca}$ but containing adequate $\mathrm{P}$ ) during the period of rapid growth in the first 3 months after weaning. During the next 6 months the retention dropped to some $15 \%$ and thereafter declined more slowly. It is noteworthy that between 21 and 24 months these animals were just in balance.

Animals in groups 2 and 3 , on the other hand, from 3 months onwards, retained Ca from diet 24I much less efficiently than those of group I; by the time they were I 5 months old rats in both groups were in negative balance during the metabolic tests: this result was more marked in group 3 than in group 2. The metabolic tests on their own diets with groups 2 and 3 at 17 months showed them to be in positive balance, but the balance on diet $24 \mathrm{I}$ was negative at the test $\mathrm{I}$ month later.

Changes in the faecal $\mathrm{Ca}$ excretion show that the observed decrease in retention of $\mathrm{Ca}$ was due to poorer absorption. As the age of the rats increased, the daily faecal excretion of $\mathrm{Ca}$ rose from about $\mathrm{I} \mathrm{mg}$ to $30-40 \mathrm{mg}$, though the $\mathrm{Ca}$ intake was only doubled. During the first 18 months the faecal $\mathrm{Ca}$ was highest in group 3 and lowest in group $\mathrm{r}$. No consistent difference was found in the urinary $\mathrm{Ca}$ of the three groups, but the daily excretion increased from about $0.4 \mathrm{mg}$ daily in young animals to over $3 \mathrm{mg}$ in adults. 

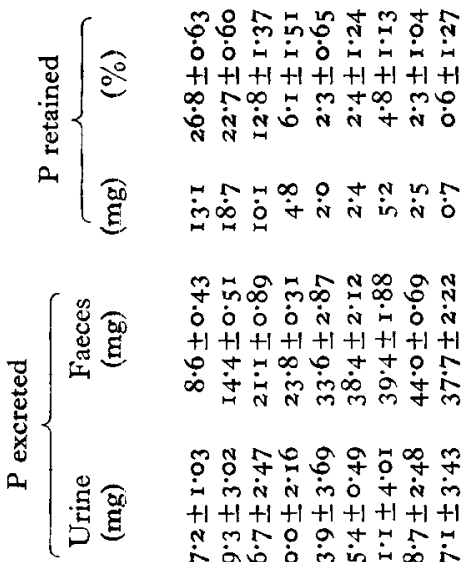

马ंกี $\dot{0} \dot{0} \dot{0} \dot{0} \dot{N} \dot{N} \dot{i} \dot{0} \dot{N}$ $+1+1+1+1+1+1+1+1+1$

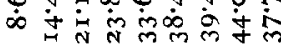

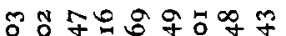

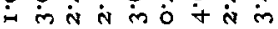
$+1+1+1+1+1+1+1+1+1$

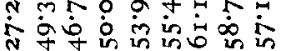

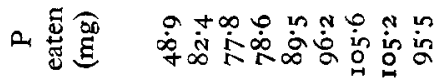

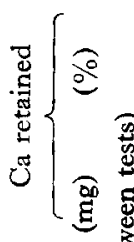
约

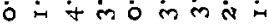
$+1+1+1+1+1+1+1+1+1$

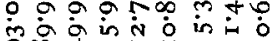
恋

mttmonom nom $\overbrace{\mathbb{2}}$

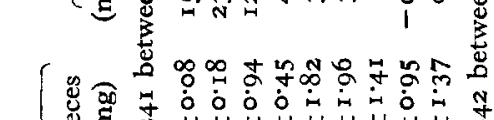

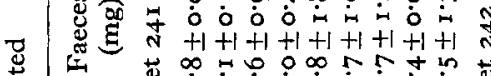

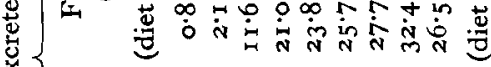
능

范

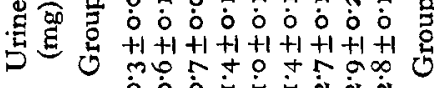

Uึ

Hovitand

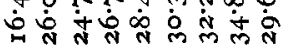

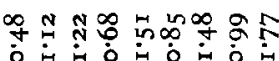

岂焉

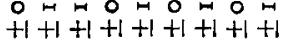

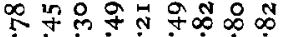

त त ल

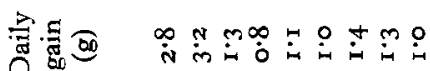

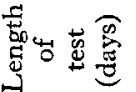

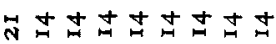

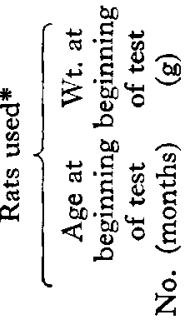

anno $0 \infty \circ 0 m$

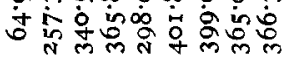

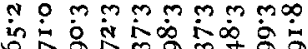

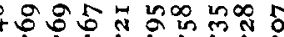
0
0 क

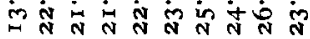

4⿻一力口

0 o $m$ in is $\dot{\alpha}$ in 2

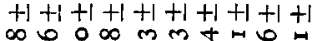

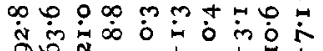

1

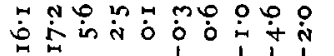

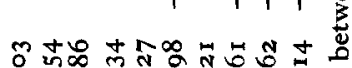
$\dot{0}$ in $\dot{0}$ o $+1+1+1+1+1+1+1+1+1+1$ ते ód

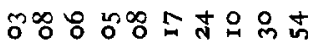

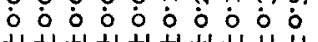
$\mathrm{H}+1+\mathrm{H}+\mathrm{H}+\mathrm{H}+\mathrm{H}+\mathrm{H}+1$

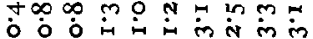

magotom NNm

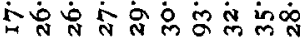

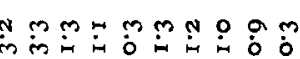

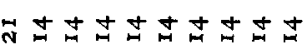

\section{象}

matoronnom

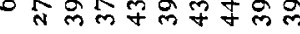

$\operatorname{mog} \min _{n \rightarrow 4}$

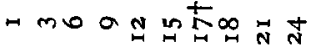

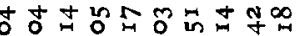

- o d o jo ó do 0 o o

$+1+1+1+1+1+1+1+1+1+1$

ơ

aramaman

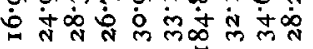

๓

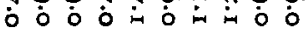
$+1+1+1+1+1+1+1+1+1+1$

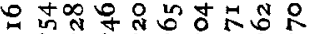
iी

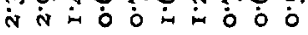

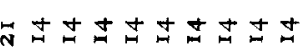
n A A A A A

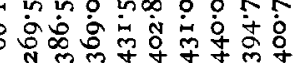

- mo a n m

$\dot{0} 0 \dot{0} \dot{0} \dot{0} \dot{0}$ $+1+1+1+1+1+1+1+1$ in in

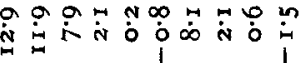

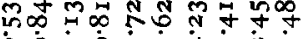
$+1+1+1+1+1+1+1+1+1+$ 
Table 3. Exp. I. Mean values for analyses of right humerus and femur of rats treated exactly as their counterparts described in Table 2 and killed at the end of the metabolic tests with these. Analyses of the bones of the metabolic rats at the end of that experiment are also given. Ash, Ca and $P$ expressed as percentage of the dry fatfree bone

(Litter-mate comparisons between groups, three rats for each analytical figure)

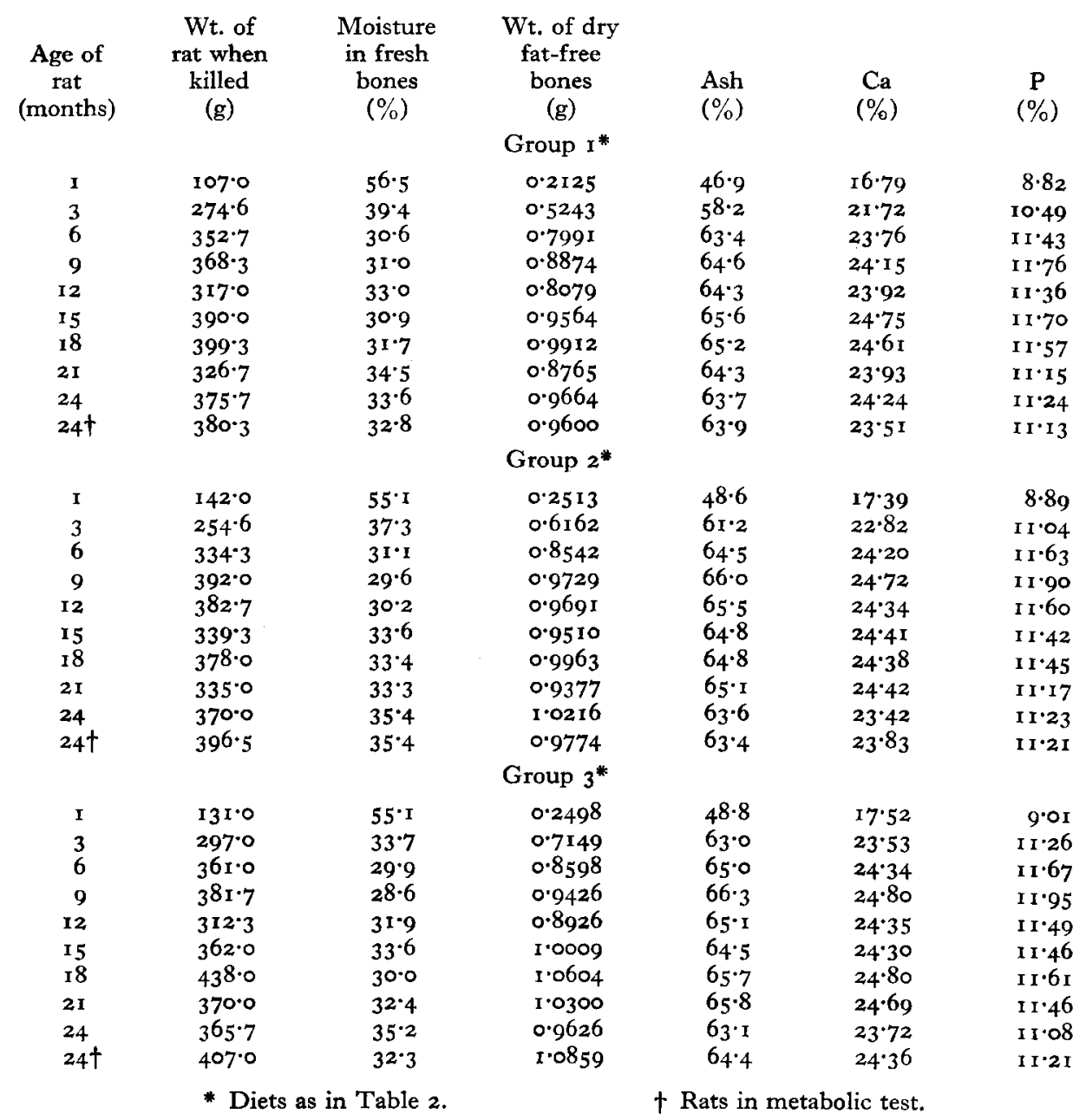

\section{Metabolism of phosphorus}

The retention of $\mathbf{P}$, although lower, was roughly parallel with that of $\mathrm{Ca}$; a rapid drop occurred in all groups during the first 12 months of the experiment and thereafter there was little change, the animals in all groups remaining just in $\mathrm{P}$ balance. After I month group I retained more $\mathrm{P}$ (absolute and \%) than groups 2 and 3 ; for the first 12 months retention was better by group 2 than by group 3 , but subsequently there was no consistent differentiation. All groups excreted more $P$ in the urine than in the faeces. This was to be expected, since the diet contained a relative excess of $\mathrm{P}$ over $\mathrm{Ca}$. 
As with $\mathrm{Ca}$, the faecal excretion of $\mathrm{P}$ increased with increasing $\mathrm{Ca}$ content of the diet eaten in the intervals between metabolic tests, but no consistent differences were found between the urinary $\mathrm{P}$ outputs of the three groups.

\section{Analyses and $X$-ray examination of the bones}

The results of the bone analyses (Table 3 ) were in general agreement with those of the balance experiments. In all groups calcification was rapid during the first 6 months and remained steady thereafter. The figures suggest that between 18 and 24 months the bone Ca may have decreased slightly. At first the rate of calcification was somewhat less rapid in group 1 , but by $9-12$ months the bones were equally calcified in all groups (cf. Lanford \& Sherman, 1938; Lanford, Campbell \& Sherman, 1941). Our $\mathrm{Ca}$ and $\mathrm{P}$ values for the appropriate ages are in agreement with those quoted by Hammett (1925) for normal albino rats aged 23-150 days. The composition of the bones of the rats used in the metabolic tests and killed when 24 months old was similar to that of the 24 -month control animals.

$\mathrm{X}$-ray photographs failed to show any differences in calcification between the groups, except in the 3 -month-old animals where the photographs showed that calcification was rather better in groups 2 and 3 than in group $\mathrm{I}$.

\section{Effect of prolonged feeding of the low-calcium diet on the metabolism of calcium}

The metabolic test carried out when the animals were 24 months old and had received the low-Ca diet for the previous 3 months showed that, although in groups 2 and 3 they were still in negative $\mathrm{Ca}$ balance, they were nevertheless losing less $\mathrm{Ca}$ from their bodies than at 21 months. This finding may be taken to indicate that the animals in these two groups were slowly adjusting themselves to the lowered $\mathrm{Ca}$ intake.

\section{Exps. 2, 3 and 4. Effect of vitamin $D$ on the retention of calcium by the adult rat}

Table 4 gives the mean data for $\mathrm{Ca}$ and $\mathrm{P}$ balances and Table 5 the statistical analysis of some of the results for Exps. 2, 3 and 4. Table 6 gives the results of the bone analyses done in Exps. 2 and 3.

\section{Metabolism of calcium}

In Exps. 2 and 3 animals were maintained on a diet high in $\mathrm{Ca}$ and $\mathrm{P}$, with or without vitamin $\mathrm{D}$, until they were 12 and 9 months old respectively. Vitamin D subsequently given to those originally deprived of it had no effect on the retention of Ca whether the rats continued on the diet high in minerals (Exp. 2) or were changed to one relatively low in them (Exp. 3).

Allowing for slight differences in age, the results of the first metabolic periods in Exp. 4 confirm those of Exps. 2 and 3 ; groups I and 2 being comparable with the rats in Exp. 2 (test at $I$ year) and groups 3 and 4 with those in Exp. 3. No significant differences in $\mathrm{Ca}$ retention were observed between the two metabolic periods with any of the groups in Exp. 4. The results for group 4 do not confirm the findings of Nicolaysen (1943). 
$\frac{\bar{\Xi}}{8}$

$\frac{N}{x}$

. ก

2

รี

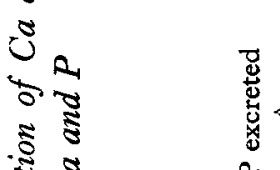

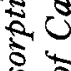

8

5

ค ป

- ำ

-

ㄱ.

ปัँ

พ

ड़े डे

8

ह ह

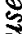

i

8

5

2

ฐ

2.

ป⿱

곤

$\dot{+}$

ह

$m$

n

趈

$\dot{+}$

营

离

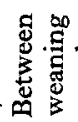

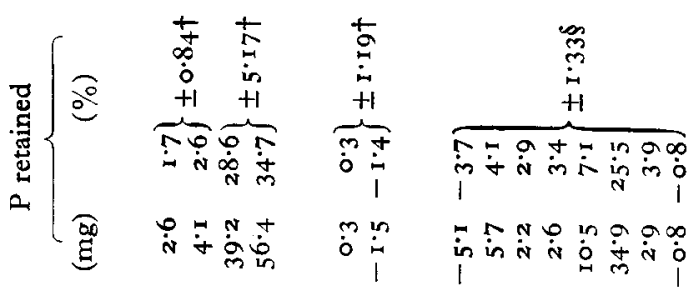

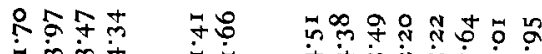
$+1+1+1+1 \quad+1+1 \quad++1+1+1+1+1+1+1$ 以

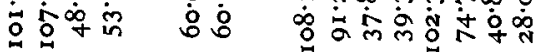

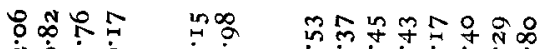

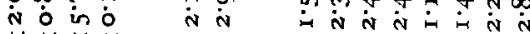
$+1+1+1+1 \quad+1+1 \quad+1+1+1+1+1+1+1+1$

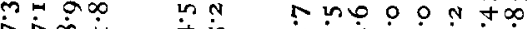

苟告

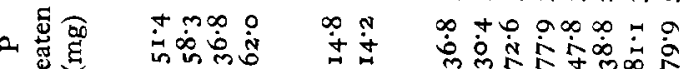

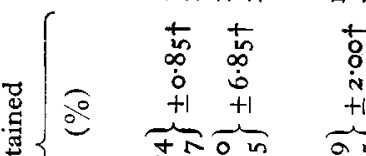

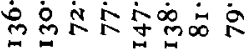

$\overleftarrow{8} \quad$ con

$+1$

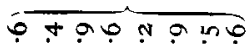

$\forall \hat{i}$ in $\dot{0} \dot{0} \dot{i} \dot{\infty}$

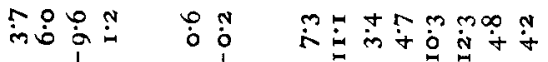

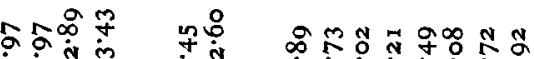

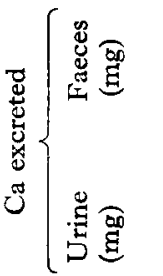

iक्य

in in 0

$+1+1+1+1+1+1+1+1$

n $N$ N

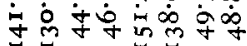

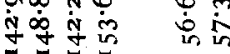

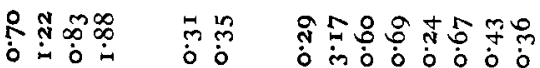

$+1+1+1+1+1+1+1+1$

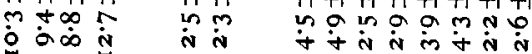

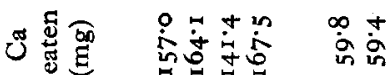

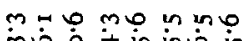

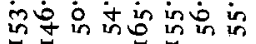

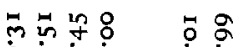

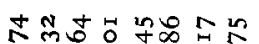

o

$+1+1+1+1+1+1+1+1$

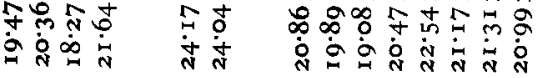

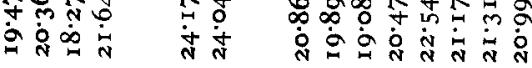

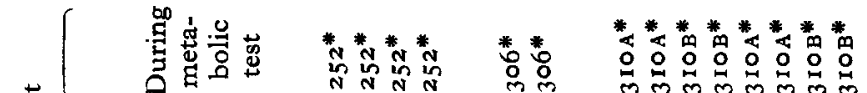

ํำ

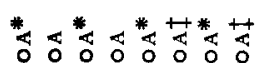

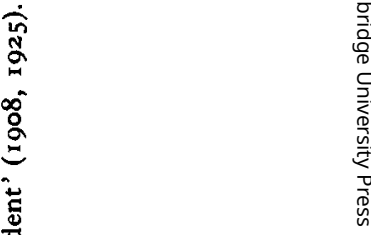

ठ

晜

क

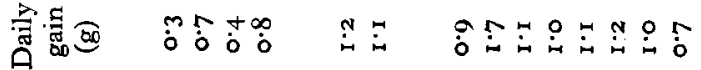

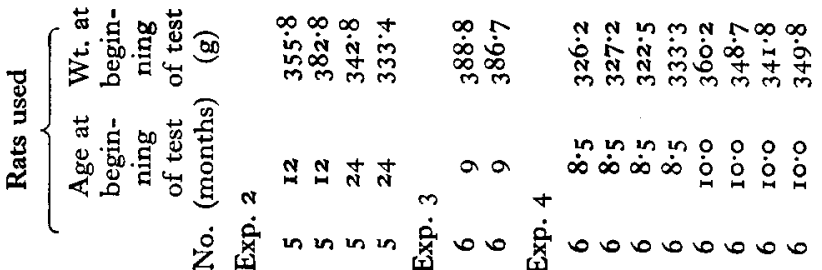


Table 5. Exp. 4. Analysis of variance of differences in percentage retention of $\mathrm{Ca}$ and $P$

\begin{tabular}{|c|c|c|c|}
\hline \multirow[b]{2}{*}{ Component } & \multirow{2}{*}{$\begin{array}{l}\text { Degrees of } \\
\text { freedom }\end{array}$} & \multicolumn{2}{|c|}{ Mean squares } \\
\hline & & $\begin{array}{c}\text { Ca retention } \\
(\%)\end{array}$ & $\begin{array}{l}\text { P retention } \\
(\%)\end{array}$ \\
\hline Litters & 5 & $I I \cdot I 2$ & 15.61 \\
\hline Age & I & $9 \cdot 19$ & $630.03 * * *$ \\
\hline Diets & 3 & $16 \cdot 80$ & $492 \cdot 86 * * *$ \\
\hline Litters $\times$ age & 5 & $6 \cdot 81$ & $3 x \cdot 49^{*}$ \\
\hline Dicts $\times$ age & 3 & $6 \cdot 96$ & $382 \cdot 8 * * *$ \\
\hline Error & 30 & 13.69 & 10.69 \\
\hline
\end{tabular}

Table 6. Exps. 2 and 3. Analyses of the right humerus and femur of rats described in Table 4 and killed at the end of the metabolic tests, together with analyses for littermate controls killed at the same time but given no vitamin $D . A s h, C a$ and $P$ expressed as percentage of the dry fat-free bone

\begin{tabular}{|c|c|c|c|c|c|c|c|c|c|}
\hline \multirow[b]{2}{*}{$\begin{array}{l}\text { No. } \\
\text { of } \\
\text { rats }\end{array}$} & \multirow[b]{2}{*}{$\begin{array}{c}\text { Age } \\
\text { of } \\
\text { rats } \\
\text { (months) }\end{array}$} & \multirow[b]{2}{*}{$\begin{array}{l}\text { Wt. of } \\
\text { rats when } \\
\text { killed } \\
(\mathrm{g})\end{array}$} & \multicolumn{2}{|c|}{ Diet } & \multirow[b]{2}{*}{$\begin{array}{c}\text { Moisture } \\
\text { in fresh } \\
\text { bones } \\
(\%)\end{array}$} & \multirow[b]{2}{*}{$\begin{array}{l}\text { Wt. of dry } \\
\text { fat-free } \\
\text { bones } \\
\text { (g) }\end{array}$} & \multirow[b]{2}{*}{$\begin{array}{l}\text { Ash } \\
(\%)\end{array}$} & \multirow[b]{2}{*}{$\begin{array}{c}\mathrm{Ca} \\
(\%)\end{array}$} & \multirow[b]{2}{*}{$\underset{(\%)}{\mathbf{P}}$} \\
\hline & & & $\begin{array}{l}\text { Between } \\
\text { weaning } \\
\text { and meta- } \\
\text { bolic test }\end{array}$ & $\begin{array}{c}\text { During } \\
\text { meta- } \\
\text { bolic } \\
\text { test }\end{array}$ & & & & & \\
\hline \multicolumn{10}{|c|}{ Exp. 2} \\
\hline 5 & 12 & 360.4 & $252^{*}$ & $252^{*}$ & $28 \cdot 4$ & 0.9754 & $66 \cdot 2$ & 24.97 & 11.80 \\
\hline 5 & 12 & $393^{\circ} \circ$ & 252 & $252^{*}$ & $28 \cdot 4$ & 0.9979 & $66 \cdot 5$ & $24 \cdot 96$ & $11 \cdot 37$ \\
\hline 5 & 12 & $377 \cdot 8$ & 252 & 252 & 29.4 & $I \cdot 0463$ & 65.9 & $24 \cdot 73$ & II 7 I \\
\hline 5 & 24 & $348 \cdot 6$ & $252^{*}$ & $252^{*}$ & $30 \cdot 6$ & I.0374 & $65 \cdot I$ & $24 \cdot 63$ & $11 \cdot 39$ \\
\hline 5 & 24 & $344 \cdot 8$ & 252 & $252^{*}$ & $33^{\circ} \circ$ & I. 0684 & $64 \cdot 2$ & $24 \cdot 24$ & I $1 \cdot 35$ \\
\hline 4 & 24 & $363 \cdot 5$ & 252 & 252 & $32 \cdot 3$ & $I \cdot 0484$ & 63.9 & $24: 13$ & 11.23 \\
\hline \multicolumn{10}{|c|}{ Exp. 3} \\
\hline 6 & 9 & $406 \cdot 0$ & $252^{*}$ & $306 *$ & $29 \cdot 7$ & $1 \cdot 0113$ & $65 \cdot 3$ & $24 \cdot 44$ & 10.60 \\
\hline 6 & 9 & $402 \cdot 2$ & 252 & $306 *$ & $30 \cdot 6$ & 0.9877 & 65.4 & 25.39 & 10.66 \\
\hline 6 & 9 & $367 \cdot 2$ & 252 & 306 & 30.4 & 0.9607 & 64.6 & $24 \cdot 77$ & II 164 \\
\hline
\end{tabular}

\section{Metabolism of phosphorus}

Two of the findings on $P$ retention deserve comment. In Exp. $2 \mathrm{P}$ retention was much better in the 2-year- than in the I-year-old rats, and in Exp. $4 \mathrm{P}$ retention in group $\mathrm{I}$, and more particularly in group 2 , was better in the 9-month than in the 8-month-old rats. In all three instances animals had been maintained on a high-Ca diet from weaning. These increases in $\mathrm{P}$ retention were largely accounted for by decreases in faecal $P$.

\section{Analyses and $X$-ray examination of the bones}

The bone analyses in Exps. 2 and 3 showed that calcification was the same whether vitamin $\mathrm{D}$ was given throughout, during metabolic tests only or not at all. They confirm the conclusion drawn from the balance experiments that in the adult rat assimilation of $\mathrm{Ca}$ is independent of the vitamin $\mathrm{D}$ intake when the $\mathrm{Ca}$ and $\mathrm{P}$ content of the diet is adequate.

Similarly, X-ray examination showed no differences in calcification. 


\section{DISCUSSION}

Our earlier experiments (Henry \& Kon, 1947) showed that rats maturing on a stockcolony diet with about $0.5 \% \mathrm{Ca}$ retained $\mathrm{Ca}$ progressively less well from a diet, given at intervals, containing only $0.13 \% \mathrm{Ca}$, and that finally at 2 years old they were in negative balance on this diet. The results of Exp. I confirm and amplify this earlier finding. Thus I 8-month-old animals in $\mathrm{Ca}$ balance with diets containing about $0.4 \%$ (group 2) or $0.8 \%$ (group 3) $\mathrm{Ca}$ went into negative balance if given a low-Ca diet $(0.13 \% \mathrm{Ca})$; the effect was more marked with the diet richer in $\mathrm{Ca}$. The findings of Kane \& McCay (1947) are similar, as in their experience old rats placed on a diet containing $0.3 \%$ Ca were in negative balance, whereas young rats so treated retained $\mathrm{Ca}$ efficiently.

It was only when changed to a diet much lower in $\mathrm{Ca}$ that old rats given ample $\mathrm{Ca}$ throughout life went into negative balance; they remained in equilibrium on the Ca-rich diets to which they were accustomed (Henry \& Kon, I947, and present work). We explained by increased katabolism of the skeleton in senescence this growing inability of the ageing rat to adapt itself to a lowered intake of $\mathrm{Ca}$ (Henry \& Kon, r947). We had not studied at that time the behaviour of rats always frugally endowed with $\mathrm{Ca}$. Such observations are available in the present study and it may be said at once that they are in striking contrast with findings on rats accustomed to high-Ca diets. At first the rats given low-Ca diets deposited it less rapidly than those receiving much more of the element. However, they went on depositing $\mathrm{Ca}$ for longer, although more slowly in the initial stages, and at 12 months their skeletons were as well mineralized as those of rats on the more generous intake. If the metabolism of $\mathrm{Ca}$ of the adult or senescent rat was, as in the growing stage, primarily related to the body stores (cf. Henry \& Kon, I947) one would expect the old animals to be in balance on a relatively low-Ca intake irrespective of the $\mathrm{Ca}$ content of their previous diet. Our experiments show clearly that this is not so and that old rats accustomed to do with little $\mathrm{Ca}$ in the diet remain in $\mathrm{Ca}$ equilibrium in circumstances leading to $\mathrm{Ca}$ loss in rats used to a higher intake. It thus appears that not only the extent of $\mathrm{Ca}$ stores but the way they were accumulated determine in such animals the plane of $\mathrm{Ca}$ metabolism. Either the stores acquired slowly are more tenaciously held or the owner has adapted himself to a more efficient turnover of $\mathrm{Ca}$. Such adaptation is well known in human experience and there is good evidence that populations or individuals subsisting for long on diets poor in $\mathrm{Ca}$ manage to do with much smaller amounts than those normally believed necessary (Basu, Basak \& Sircar, 1939; Nichols \& Nimalasuriya, 1939; Owen, Irving \& Lyall, I940; Steggerda \& Mitchell, I94I; Kraut \& Wecker, I943, I947-8; Mitchell, I944; De \& Som, I948; Walker, Fox \& Irving, I948; British Medical Association, 1950; Nicholls, 195 I ; Walker, I95 I Hegsted, Moscoso \& Collazos Ch., r952). In our earlier experiments (Henry \& Kon, I947) old rats showed no evidence of adaptation after a fortnight. In the present work, however, 3 months on a low-Ca diet brought about a clear improvement in retention. Three months in the life-span of a rat may well be equivalent to some 8 years in man; in fact much of the evidence just cited indicates that in man adaptation is slow and prolonged. 
In our experiments just reviewed all rats received ample vitamin D. Our other experiments in which the effect of vitamin D was studied failed to support the claims of Nicolaysen (1943) that in growing rats there is an endogenous factor regulating $\mathrm{Ca}$ absorption in the presence of vitamin $\mathrm{D}$ but not in its absence. In rats receiving high-Ca diets we observed no effects on calcification attributable to vitamin D. Our findings are essentially in agreement with those of Zucker \& Zucker (I946), who, using 49-day-old rats, found no increase in bone ash when vitamin $\mathrm{D}$ was given to those receiving diets containing $2 \cdot 2 \% \mathrm{Ca}$ and $\mathrm{r} \cdot 2 \% \mathrm{P}$, or $\mathrm{r} \cdot 0 \% \mathrm{Ca}$ and $0.56 \% \mathrm{P}$. Bone ash was slightly low with unsupplemented diets containing $0.6 \% \mathrm{Ca}$ and $0.4 \% \mathrm{P}$, and this was rectified by the addition of vitamin $\mathrm{D}$.

\section{SUMMARY}

I. The retention of calcium by rats from a diet containing only $0.13 \% \mathrm{Ca}$ and $0.4 \%$ phosphorus (diet 24I) was determined in three groups of rats at approximately 3 -monthly intervals between the ages of $I$ and 21 months. Between metabolic periods the animals were given diets containing about $0.13 \% \mathrm{Ca}$ and $0.4 \% \mathrm{P}$ (group I); $0.4 \% \mathrm{Ca}$ and $0.6 \% \mathrm{P}$ (group 2); $0.8 \% \mathrm{Ca}$ and $0.8 \% \mathrm{P}$ (group 3). Between $2 \mathrm{I}$ and 24 months all animals were given the low-Ca diet (diet 24I) and a further metabolic test was done with this diet at 24 months. All animals were given cod-liver oil throughout the experiment.

2. In a parallel test rats were treated in exactly the same way, but no metabolic tests were done; after feeding periods corresponding to the metabolic tests, littermates were killed in the three groups, the humeri and femora being analysed for moisture, ash, $\mathrm{Ca}$ and $\mathrm{P}$.

3. The retention of $\mathrm{Ca}$ from diet $24 \mathrm{I}$ decreased in all three groups as the age of the rats increased. This effect was more marked in groups 2 and 3 where, from 15 months onwards, the animals were in negative $\mathrm{Ca}$ balance on diet $24 \mathrm{I}$ although they were in balance on their basal diets at 17 months.

4. The negative balances in groups 2 and 3 at 21 months became less when the animals were then maintained on diet 24I until they were 24 months old.

5. Bone analyses showed that, initially, the rate of calcification depended on the $\mathrm{Ca}$ content of the diet, but that by the time the rats were I year old calcification was similar in all groups and did not change during the next year.

6. It is suggested that before calcification is complete the retention of $\mathrm{Ca}$ by the rat, from a diet low in this element, is influenced by its body stores of Ca. When calcification is complete it seems likely that the negative balances observed on changing to a lower level of intake are due to slow adaptation to this lower intake.

7. In a second series of experiments rats were reared on diets containing $0.7-0.8 \% \mathrm{Ca}$ and $\mathrm{P}$ with or without the addition of vitamin $\mathrm{D}$. When the animals were 8-12 months old they were all given vitamin $\mathrm{D}$ and the retention of $\mathrm{Ca}$ was determined from these diets or from diets containing about $0.25 \% \mathrm{Ca}$ and $0.4 \% \mathrm{P}$.

8. Vitamin $\mathrm{D}$ had no effect on the Ca metabolism of the rat, whether the diet contained high $(0.8 \%)$ or relatively low $(0.25 \%)$ amounts of $\mathrm{Ca}$. The results do not 
support the view of Nicolaysen (1943) that Ca metabolism in the rat is controlled by an endogenous factor effective only in the presence of vitamin $D$.

We wish to express our thanks to $\mathrm{Dr} M$. E. Coates for making the X-ray examination of the bones, to Miss M. V. Chapman for help with the feeding of the rats and to Miss V. Glover for help with some of the phosphorus determinations.

\section{REFERENCES}

Ackroyd, H. \& Hopkins, F. G. (1916). Biochem. F. ro, 55 I.

Basu, K. P., Basak, M. N. \& Sircar, B. C. R. (1939). Indian F. med. Res. 27, 47I.

British Medical Association (r950). Report of the Committee on Nutrition. London: British Medical Association.

De, H. N. \& Som, A. B. (1948). Indian F. vet. Sci. 18, 241.

de Loureiro, A. (193 I). Arch. Pat., Lisboa, 3, 72.

Fairbanks, B. W. \& Mitchell, H. H. (1936). F. Nutr. II, 55 I.

Folley, S. J., Ikin, E. W., Kon, S. K. \& Watson, H. M. S. (1938). Biochem. F. 32, 1988.

Hammett, F. S. (1925). F. biol. Chem. 64, 685 .

Hegsted, D. M., Moscoso, I. \& Collazos Ch., C. (1952). F. Nutr. 46, r31.

Henry, K. M. \& Kon, S. K. (1937). Milk and Nutrition, part 1, p. 9. Reading: National Institute for Research in Dairying.

Henry, K. M. \& Kon, S. K. (1947). Biochem. F. 4r, x69.

Kane, G. G. \& McCay, C. M. (1947). F. Geront. 2, 244.

Kraut, H. \& Wecker, H. (1943). Biochem. Z. 315, 329.

Kraut, H. \& Wecker, H. (1947-8). Biochem. Z. 318, 495.

Lanford, C. S., Campbell, H. L. \& Sherman, H. C. (r941). F. biol. Chem. 137, 627.

Lanford, C. S. \& Sherman, H. C. (1938). F. biol. Chem. 126, 38ז.

McCay, C. M., Crowell, M. F. \& Maynard, L. A. (1935). F. Nutr. ro, 63.

Macy, I. G. (1942). Nutrition and Chemical Growth in Childhood, Vol. 1. Springfield, Ill.: C. C. Thomas.

Meulengracht, E. (1938). Lancet, 235, 774 .

Mitchell, H. H. (1939). The Dietary Requirement of Calcium and its Significance. Paris: Herman et Cie.

Mitchell, H. H. (1944). F. Amer. diet. Ass. 20, 5 I I.

Nicholls, L. (195I). Tropical Nutrition and Dietetics, 3 rd ed. London: Baillière, Tindall and Cox.

Nichols, L. \& Nimalasuriya, A. (1939). F. Nutr. 18, 563 .

Nicolaysen, R. (1943). Acta physiol. scand. 5, 200.

Outhouse, J., Kinsman, G., Sheldon, D., Twomey, I., Smith, J. \& Mitchell, H. H. (1939). F. Nutr. I7, 199.

Owen, E. C., Irving, J. T. \& Lyall, A. (1940). Acta med. scand. 103, 235.

Rottensten, K. V. (1938). Biochem. F. 32, 1285.

Sherman, H. C. \& Booher, L. E. (r93I). F. biol. Chem. 93, 93.

Stare, F. J. (1943). Proceedings of the Research Conference on the Relation of Nutrition to Public Health, p. 7. New York: The Nutrition Foundation.

Steggerda, F. R. \& Mitchell, H. H. (1941). F. Nutr. 21, 577.

'Student' (1908). Biometrika, 6, I.

'Student' (1925). Metron, 5, 105.

Todd, T. W. (1942). In Problems of Ageing [E. V. Cowdry, editor], and ed., p. 322. Baltimore: The Williams and Wilkins Co.

Walker, A. R. P. (1951). F. Amer. med. Ass, 145, 49.

Walker, A. R. P., Fox, F. W. \& Irving, J. T. (1948). Biochem. F. 42, 452.

Zucker, T. F. \& Zucker, L. M. (1946). Amer. F. Physiol. 146, 585. 